\title{
REACTIVE DYE PRINTING ON COTTON FABRIC USING MODIFIED STARCH OF WILD TARO CORMS AS A NEW THICKENING AGENT
}

\author{
RATTANAPHOL MONGKHOLRATTANASIT, ${ }^{*}$ CHAROON KLAICHOI* and \\ NATTADON RUNGRUANGKITKRAI** \\ "Faculty of Industrial Textiles and Fashion Design, \\ Rajamangala University of Technology Phra Nakhon, Bangkok 10300, Thailand \\ ** Department of Textile Science, Faculty of Agro-Industry, \\ Kasetsart University, Bangkok 10900, Thailand \\ \Corresponding author: R. Mongkholrattanasit, rattanaphol.m@rmutp.ac.th
}

Received August 16, 2021

This study investigated the use of a thickening agent derived from modified starch of wild taro corms in the screen printing of cotton fabric using reactive dye. The best conditions for developing the print paste and steaming time in order to obtain maximum color yield were established. The results revealed impressive color fastness properties in the printed samples; although, the printed fabric possessed slightly lesser tensile and tear strength, in comparison with the unprinted fabric. The printed fabric also exhibited increased bending stiffness properties. Largely, this study reveals that the printing paste containing the thickening agent derived from carboxymethyl starch within wild taro corms can be utilized in the printing of cotton fabric using reactive dye.

Keywords: printing, reactive dye, cotton, thickening agent, wild taro corm, modified starch

\section{INTRODUCTION}

Textile printing is an ancient art, dating back a few thousand years and is still currently practiced today. ${ }^{1-2}$ The art of textile printing is practiced to produce attractive, colorful designs, with welldefined boundaries, which are creatively arranged into motifs or emblems. ${ }^{2}$ Printing can bring any textile material to maturity by conferring flexibility to it for fashion design. ${ }^{2}$ Screen printing is one of the oldest and most versatile printing techniques, where a mesh screen is used to transfer ink or dye to the substrate, fabric in this instance, to create the design. ${ }^{3}$ A high amount of printing medium can be applied to the substrate using the screen printing technique, thus increasing print thickness. ${ }^{3}$ Dyes or pigments are used to achieve coloration in the printing paste. ${ }^{3-4}$ Correct colors, sharply defined edges, even distribution of the print paste, a steady hand and efficient use of the dye are all vital to achieving a successful print. All the aforementioned factors are dependent on the type of thickening agent used and the flow of the resultant print paste..$^{4-5}$ Dye-based print pastes comprise a complex combination of numerous components. In addition to water, dye, thickener, and $\mathrm{pH}$ buffer, the paste also may contain binding agents and other auxiliaries. ${ }^{6}$

The thickening agent is an essential component of the print paste, particularly in the process of reactive dye printing of cellulosic textiles. It plays a major role in ensuring sharp and clean drawing patterns through modulation of the rheological properties. ${ }^{7}$ A thickening agent is generally a natural or synthetic water-soluble polymer with a high molecular weight. It is also termed a hydrocolloid and produces a sticky colloidal solution. For the maximum amount of dye to be transferred from the print paste to the fabric, the thickening agent, when holding the solubilized dye particles, should have a lower affinity for the dye, compared to the fabric being printed. Starch, due to its availability and low cost, has become a most popular natural thickening agent. The use of native starch in many industrial applications does have disadvantages however, because of its low water solubility, easy thermal decomposition, high retrogradation, and low shear stress resistance. ${ }^{7}$ In addition, native 
starch has a large quantity of hydroxyl groups present on the molecule, which form complex crosslinking with the reactive dye. This inhibits the transfer of the dye from the printing paste to the fabric during steaming and the removal of printing paste during washing, resulting in a bad color yield and fabric rigidity. ${ }^{7}$ It is, therefore, required to modify native starch to decrease the reactivity of its hydroxyl groups. In order to overcome these limitations and to achieve the required properties, native starch can be altered chemically, physically, or enzymatically. ${ }^{7}$

Carboxymethyl starch (CMS) is the most widely used thickener to date. It is an anionic starch that is acid and alkaline stable within the $\mathrm{pH}$ range of printing pastes, and therefore, it is used with a wide range of dyes., ${ }^{3,-8} \mathrm{CMS}$ is synthesized by the reaction of starch with monochloroacetic acid or its sodium salt, following activation of the polymer with sodium hydroxide in an aqueous, organic solvent slurry, which, in most cases, is an alcohol. ${ }^{3,7-10}$ The hydroxyl group of the carbon atoms $\mathrm{C} 2, \mathrm{C} 3$, and C6 are usually substituted by the carboxymethyl group, depending on the degree of substitution. ${ }^{3,11}$ However, only sodium CMS with a substitution degree of two or higher can currently be used as thickening agent and flow improver for reactive printing. ${ }^{3,7}$

Reactive printing is the most commonly used method for cotton due to its high wet fastness, brilliant color, and range of hues. ${ }^{12-14}$ Nowadays, cotton fiber is the most globally utilized natural fiber with $75 \%$ of print cotton materials printed with reactive dyes. ${ }^{15}$ The structure of the thickening agent selected for reactive printing must comprise some functional groups that have strong affinity for reactive dyes. ${ }^{13}$ Anionic thickening agents are therefore preferred alternatives due to the mutual repulsion between their anion groups and the sulfonic acid groups on dyes. This repulsion also promotes the migration of the dye from the printing film into the fibers during steaming. ${ }^{13}$

Wild taro (Colocasia esculenta (L.) Schott is a vegetatively propagated root crop species of the monocotyledonous family Araceae and is cultivated in almost all tropical and subtropical regions of the world. ${ }^{16}$ Wetlands in Thailand have experienced a loss of habitat for native plant species because of the invasion of wild taro. ${ }^{17}$ The wild taro plant is characterized by large elephant ear-like leaves and grows to a height of 1-1.5 m. ${ }^{18}$ Figure 1 shows the leaves and corms of wild taro. The corm of the wild taro is composed of $63-85 \%$ water, $13-29 \%$ starch, $1.3-4.0 \%$ protein, $2.0-4.0 \%$ fat, $0.6-1.3 \%$ ash, $0.6-1.2 \%$ fibre, and a small amounts of vitamin C. ${ }^{19}$ The entire wild taro plant contains an insoluble, needle-like crystal called calcium oxalate, which causes irritation to the mouth, throat, and stomach if not properly and fully cooked prior to eating. ${ }^{20-21}$ The increased demand for starch and its growing use at an industrial level brought about the need to source it from underutilized and lesser-known grains and legumes, such as crops that are usually cheap and widely available. One such crop is wild taro corm, which, due to its high starch content, compares favorably with other highly commercialized legumes, such as pea and corn.

Among starch derivatives, CMS is particularly important as it can be utilized in a wide array of industrial applications, such as textiles, food, pharmaceuticals, paper, plastic, and biomedical agents. ${ }^{22-23}$ Many types of starch, such as those obtained from corn, potato, chestnut, cassava, sago, tamarind kernel powder, sorghum, pea, cocoyam and water yam, have been used as raw materials for carboxymethylation. ${ }^{7-9,22-30}$ However, limited data are available on the possibility of using carboxymethyl wild taro corm starch for textile printing. ${ }^{31-32}$
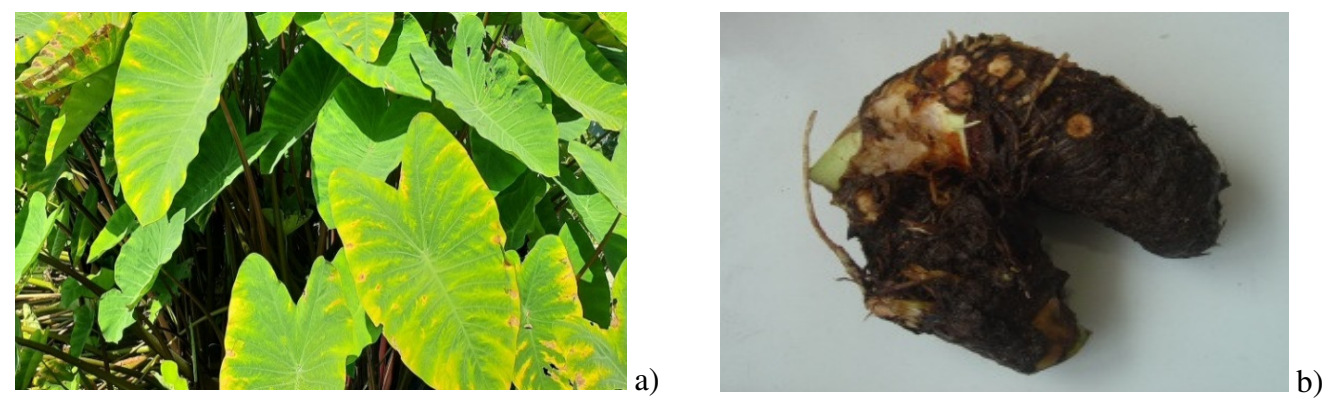

Figure 1: Wild taro (a) leaves and (b) corms 
This study examines the feasibility of utilizing new thickening agents derived from carboxymethyl wild taro corm starch to print cotton fabric using reactive dye. The printing paste was applied to cotton fabric using the screen-printing technique. The viscosity, color values, color strength, color fastness, tensile strength, tear strength and stiffness of the printed fabrics were evaluated and discussed.

\section{EXPERIMENTAL}

\section{Materials and chemicals}

Cotton fabric was purchased from a local market in Bangkok, Thailand. The weaving structure was plain weave of 51 x 55 thread/inch, with $113 \mathrm{~g} / \mathrm{m}^{2}$ weight, and a thickness of $0.25 \mathrm{~mm}$. The cotton fabric was boiled for $30 \mathrm{~min}$ in a solution of $2 \mathrm{~g} / \mathrm{L}$ of non-ionic detergent and $5 \mathrm{~g} / \mathrm{L}$ of sodium carbonate. It was then thoroughly washed and rinsed with tap water, and air dried at room temperature. The wild taro corms used in this research were collected from the Chantaburi province in Thailand. Monochloroacetic acid (MCA), sodium hydroxide, ethanol, and hydrochloric acid were of laboratory grade. Sodium bicarbonate, urea, and non-ionic soaping agent were purchased from Star Tech Chemical Industrial Co., Ltd. (Thailand). The reactive dye (Hifix Supra Blue CL) supplied by Phisit Inter Group Co., Ltd. (Thailand) was used without further purification.

\section{Preparation of carboxymethyl starch from wild taro corms}

The wild taro corms were harvested and left to dry in direct sunlight for one month, and then crumbled in a blender. The corms were then milled and ground further through a $335 \mu \mathrm{m}$ mesh sieve. ${ }^{31-32}$ The carboxymethyl reaction of the wild taro corm starch was conducted in an aqueous-organic liquid medium. The organic solvent used in this experiment was ethanol. In a $500 \mathrm{~mL}$ three-necked, flat-bottomed flask, equipped with an automated stirring mechanism, $6.4 \mathrm{~g}$ of sodium hydroxide was added to $100 \mathrm{~mL}$ of water and ethanol at a ratio of 9:1. The solution was stirred at
300 rpm until the sodium hydroxide was completely dissolved. Wild taro corm starch (10 g dry weight) was added to the mixture and was stirred at $400 \mathrm{rpm}$. After stirring for $30 \mathrm{~min}, 8.4 \mathrm{~g}$ of monochloroacetic acid (MCA) was added to the mixture, along with the reaction mixture, and then placed in a water bath with a hot magnetic stirrer. ${ }^{33}$ The reaction mixture was achieved using the reflux technique. The temperature was increased to a reaction temperature of $70{ }^{\circ} \mathrm{C}$ and the mixture was stirred for $60 \mathrm{~min}^{31-32}$ The paste was cooled at room temperature and then filtered through a suck funnel. The residue was suspended in $300 \mathrm{~mL}$ of ethanol and then neutralized using 50\% hydrochloric acid. The residue was filtered and washed with $85 \%$ ethanol numerous times. ${ }^{23}$ The slurry obtained was suspended in absolute ethanol and dried at $40-60{ }^{\circ} \mathrm{C}$ for an adequate amount of time in order to produce a dry product. ${ }^{31-32}$ The dried sample was milled, ground, and stored in a thickening agent desiccator.

\section{Preparation of printing paste}

The printing pastes were prepared according to the method shown in Table 1. The printing paste was prepared by dissolving reactive dye with urea and water. The mixture was stirred to homogenize the solution and mixed with water. The mixture was stirred to achieve a homogeneous solution. The mixed reactive dye with the urea solution was poured onto the thickener and the whole mixture was thoroughly stirred with sodium bicarbonate. The total weight of the resulting paste was then adjusted to one kilogram by the addition of the required amount of water.

\section{Printing procedures}

All the printing pastes were applied to cotton fabric using the conventional screen printing technique. ${ }^{34}$ The printed cotton fabric samples were then air dried using at $80{ }^{\circ} \mathrm{C}$ for $5 \mathrm{~min}$, and then steam-fixed at $110{ }^{\circ} \mathrm{C}$ for $30 \mathrm{~min}$. After steam fixation, the printed samples were rinsed thoroughly with cold and warm water, soaped for $10 \mathrm{~min}$ at $50{ }^{\circ} \mathrm{C}$ in $2 \mathrm{~g} / \mathrm{L}$ non-ionic soaping agent, then thoroughly rinsed again with warm and cold water, and air dried at room temperature.

Table 1

Recipe of reactive dye printing paste using carboxymethyl wild taro corm starch as thickening agent

\begin{tabular}{lccccc}
\hline Component & \multicolumn{5}{c}{ Parameters tested } \\
\cline { 2 - 6 } & $\begin{array}{c}\text { Thickening } \\
\text { agent conc. } \\
(\mathrm{g} / \mathrm{kg} \text { paste })\end{array}$ & $\begin{array}{c}\text { Urea conc. } \\
(\mathrm{g} / \mathrm{kg} \\
\text { paste })\end{array}$ & $\begin{array}{c}\text { Sodium } \\
\text { bicarbonate conc. } \\
(\mathrm{g} / \mathrm{kg} \text { paste })\end{array}$ & $\begin{array}{c}\text { Reactive dye } \\
\text { conc. } \\
(\mathrm{g} / \mathrm{kg} \text { paste })\end{array}$ & $\begin{array}{c}\text { Steaming } \\
\text { fixation time } \\
(\mathrm{g} / \mathrm{kg} \text { paste })\end{array}$ \\
\hline Thickening agent & $150-250$ & 200 & 200 & 200 & 200 \\
Urea & 50 & $10-100$ & 50 & 50 & 50 \\
Sodium bicarbonate & 10 & 10 & $1-20$ & 10 & 10 \\
Reactive dye & 10 & 10 & 10 & $1-20$ & 10 \\
Warm water & $\mathrm{X}$ & $\mathrm{X}$ & $\mathrm{X}$ & $\mathrm{X}$ & $\mathrm{X}$ \\
Total & 1000 & 1000 & 1000 & 1000 & 1000 \\
\hline
\end{tabular}




\section{Measuring the viscosity of the printing paste}

The rheological properties of the printing pastes were measured at $25{ }^{\circ} \mathrm{C}$ using a viscometer (BROOKFIELD DV-II+Pro). The apparent viscosity ( $\eta$ ) of the printing pastes at various rates of shear was calculated using the formula:

$\eta=T / \mathrm{D}$

where $T$ is the shearing stress $\left(\mathrm{dyne} / \mathrm{cm}^{2}\right)$ and $\mathrm{D}$ is the rate of shear $\left(\mathrm{S}^{-1}\right){ }^{31,35-36}$

\section{Assessment of printed samples}

The color strength (in terms of K/S value), chromatic coordinates, and $\mathrm{CIE} \mathrm{L}^{*} \mathrm{a}^{*} \mathrm{~b}^{*}$ values of the printed samples were determined using a spectrophotometer (Hunter Lab Color Quest XE, USA) with an illuminant D65 and a $10^{\circ}$ observer. The K/S value was calculated by the Kubelka-Munk equation, $\mathrm{K} / \mathrm{S}=(1-\mathrm{R})^{2} / 2 \mathrm{R}$, where $\mathrm{R}$ is the reflectance of the printed sample at the wavelength of maximum absorbance, $\mathrm{K}$ is the absorbance, and $\mathrm{S}$ is the scattering. ${ }^{34,37-38}$ The higher the K/S value, the darker the depth penetration of the print. ${ }^{39} \mathrm{~L}^{*}, \mathrm{a}^{*}$, and $\mathrm{b}^{*}$ refer to the three axes of the CIELAB colour space. The $\mathrm{L}^{*}$ value indicates luminosity, lightness from white to black. The $\mathrm{L}^{*}$ scale runs from 0 to 100 , representing the black and white reference, respectively. The a ${ }^{*}$ and $\mathrm{b}^{*}$ values indicate redness $\left(+\mathrm{a}^{*}\right)-$ greenness $\left(-\mathrm{a}^{*}\right)$, and yellowness $\left(+\mathrm{b}^{*}\right)-$ blueness $\left(-\mathrm{b}^{*}\right)$ attributes, respectively. ${ }^{40-43}$

\section{Color fastness and physical properties testing}

The color fastness properties to washing, light, rubbing, water, and perspiration of the cotton printed samples were evaluated. The tests were carried out according to ISO 105-C06 A1S: 2010, ISO 105B02:1994, ISO 105-X12: 2001, ISO 105-E01: 2013, and ISO 105-E04: 2013, respectively. The physical properties of tensile strength, tearing strength, and stiffness in terms of bending length of the fabrics were measured according to ISO13934-2: 1999, ISO 139371: 2000, and ASTM D 1388-1996, respectively.

\section{RESULTS AND DISCUSSION}

This study aimed to investigate the technical feasibility of using new thickening agents based on carboxymethyl wild taro corm starch in printing of cotton fabric with reactive dye, as well as to establish the correct conditions for achieving good quality printed fabrics with high performance properties. The following section will present the results of the investigation.

\section{Effect of thickening agent concentration}

Carboxymethyl starch is an important thickening agent for print pastes in textile printing due to its solubility and excellent stability properties, even after high-temperature fixation treatment. Furthermore, it can positively contribute to reducing the levels of solid waste and waste water pollution in the textile printing industry. ${ }^{9}$ It is especially important in the preparation of print pastes for reactive dye, as it interacts with reactive dyes to only a limited degree. $^{44}$ The effect of the thickening agent concentration on the viscosity, color values ( $\mathrm{L}^{*}$, $\mathrm{a}^{*}$ and $\left.\mathrm{b}^{*}\right)$, and color strength (K/S) are shown in Table 2. Table 2 shows that the color strength of the cotton samples printed with reactive dye was enhanced by increasing the concentration of thickening agent from $150-200 \mathrm{~g} / \mathrm{kg}$ paste. By increasing the concentration to $230 \mathrm{~g} / \mathrm{kg}$ paste, a decrease in $\mathrm{K} / \mathrm{S}$ was observed. These results can be explained by the fact that the thickening agent functioned as an auxiliary, since it created a suitable film on the surface of cotton fabric. Thus, during the steaming process, fixation of the reactive dye was possible. ${ }^{45}$ The viscosity increased from $1,754 \mathrm{cP}$ to $6,421 \mathrm{cP}$ by increasing the concentration of the thickening agent. It was noted that the printed cotton fabric was uneven, when using a concentration exceeding $230 \mathrm{~g} / \mathrm{kg}$ paste, this is because the printing paste possessed a high viscosity. Due to a fairly rough surface, it was determined that a thickening agent with lower viscosity was easier to pass through the screen, making for a more even application to the fabric. ${ }^{46}$ Also, when the printing paste has uniform surface properties, it is more easily absorbed into the cotton fiber. ${ }^{46}$ Therefore, given the results obtained, the concentration $200 \mathrm{~g} / \mathrm{kg}$ paste of thickening agent was confirmed as being optimal for the given characteristics of cotton fiber. From the color values (CIE $\mathrm{L}^{*} \mathrm{a}^{*} \mathrm{~b}^{*}$ ) analysis, the values of $a^{*}$ and $b^{*}$ were negative for the printed cotton fabric and the value of $b^{*}$ was higher than the value of $a^{*}$. This indicates a hue that is more blue than green.

\section{Effect of urea concentration}

Urea is a vital component in the printing paste of reactive dye as during the steaming process, particularly in the superheated steam immediately following printing, it causes the cotton fibers to swell, allowing the dye to rapidly penetrate the fibers. ${ }^{44,47-50}$ Therefore, urea acts as a solubilizer and disaggregating agent for reactive dyes, as well as a hydroscopic agent for swelling cotton fibers during the steaming process. ${ }^{50}$ Urea accelerates the migration of dye from the thicker film into the cotton fiber and also reduces the yellowing of cotton under hot and dry alkaline 
conditions. ${ }^{44,47-49}$ It is therefore vital to investigate the effect of urea on the printing properties of reactive dye. The effect of urea concentration on the extent of printing cotton fabric with Hifix Supa Blue $\mathrm{Cl}$ reactive dye using the new thickener was investigated (Table 3). The results revealed that color strength increases with an increased urea concentration. This was because the larger molecular structures inhibited the ability of the dyes to migrate into the inter- and intra-fiber pores of the cotton fabric. ${ }^{50}$ However, the urea increased the swelling degree of cotton and further enabled the migration of dyes into the fiber and the dye-fiber fixation reaction.

Table 2

Viscosity, color value, color strength, and obtained color at varying thickener concentrations (using $50 \mathrm{~g} / \mathrm{kg}$ urea, $10 \mathrm{~g} / \mathrm{kg}$ sodium bicarbonate and $10 \mathrm{~g} / \mathrm{kg}$ reactive dye)

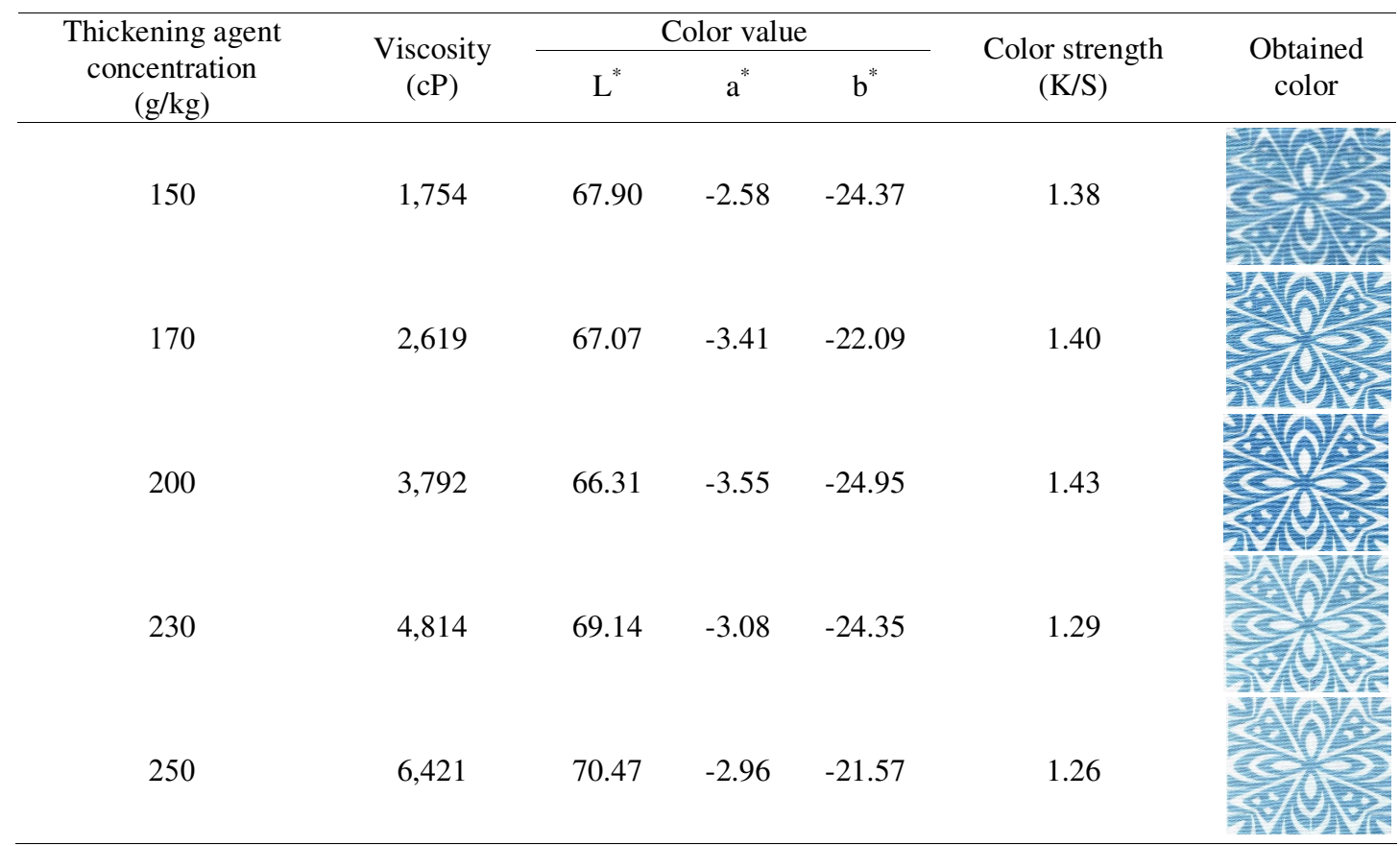

\section{Effect of sodium bicarbonate concentration}

The effect of sodium bicarbonate concentration on the extent of printing of cotton fabric with reactive dye using the new thickener was investigated (Table 4). The color strength was enhanced with the increase of the concentration of sodium bicarbonate. Sodium bicarbonate is an essential auxiliary in printing pastes as the reaction between cotton fiber and the reactive dyes can occur under alkaline conditions. ${ }^{51}$ Alkaline conditions are essential to produce ionization in accessible cellulose hydroxyl groups, which can further react with the reactive dyes in the fixation stage. ${ }^{44,47-49}$ During steaming, sodium bicarbonate loses carbon dioxide and increases the ionization of cellulose, thus promoting the dye-fiber interaction in the fixation stage. ${ }^{44,47-49}$

\section{Effect of dye concentration}

The effect of dye concentration $(1,5,10,15$, and $20 \mathrm{~g} / \mathrm{kg}$ paste) on $\mathrm{K} / \mathrm{S}$ values was determined during the printing of cotton fabrics (Table 5). The K/S increased rapidly with the concentration of the reactive dye in the printing paste. The increase in the value of K/S by increasing the concentration of the reactive dye in the printing paste was expected as the quality of colored particles in the print film increased..$^{52-54}$ Generally, the availability of dye molecules in the printing paste increases. Thus, the dye fixed on the surface of cotton supports increases with rising dye concentration, causing the color strength to become more apparent. ${ }^{55}$ 


\section{RATTANAPHOL MONGKHOLRATTANASIT et al.}

Table 3

Viscosity, color value, color strength, and obtained color at varying urea concentrations (using $200 \mathrm{~g} / \mathrm{kg}$ thickening agent, $10 \mathrm{~g} / \mathrm{kg}$ sodium bicarbonate and $10 \mathrm{~g} / \mathrm{kg}$ reactive dye)

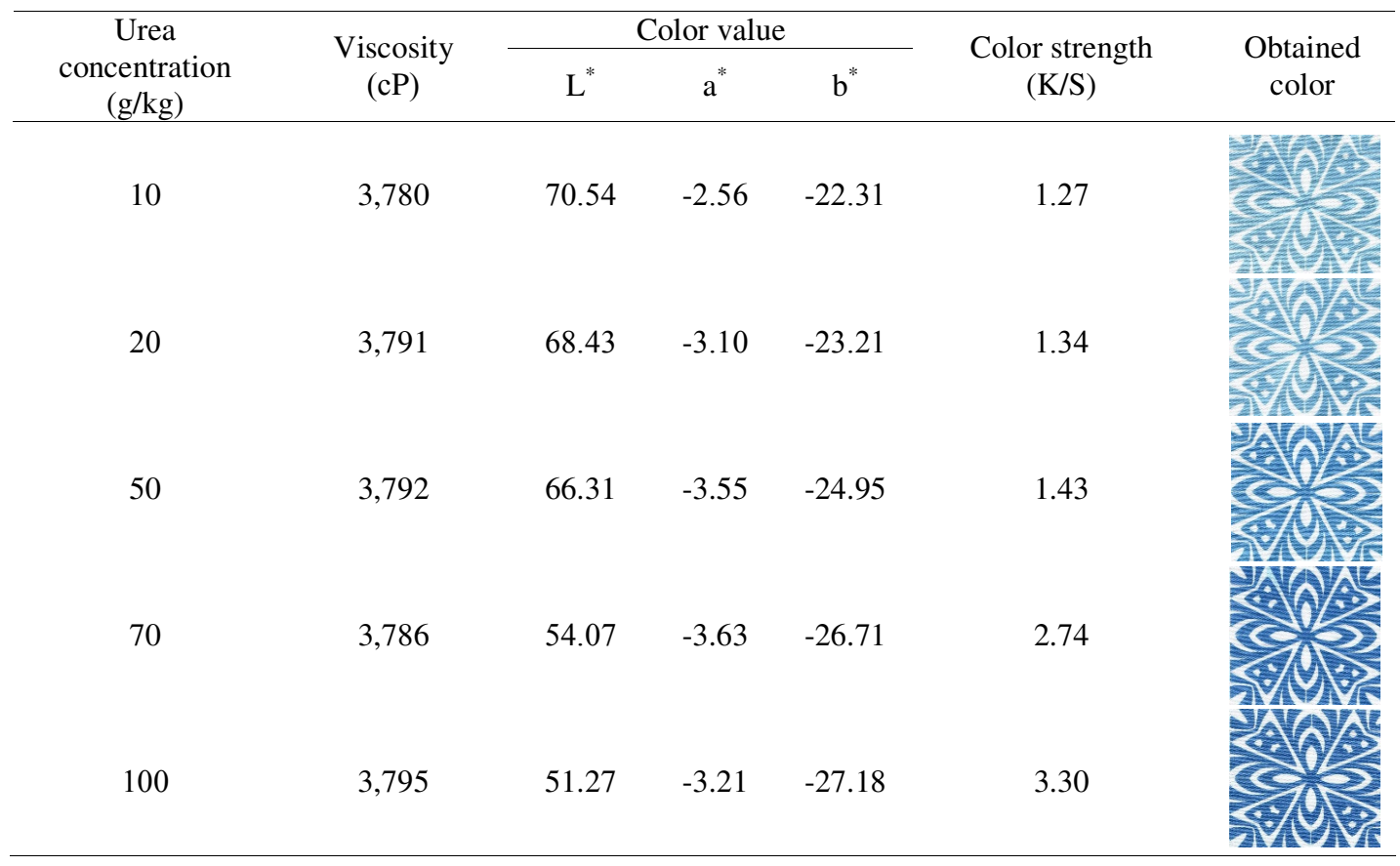

Table 4

Viscosity, color value, color strength, and obtained color at varying sodium bicarbonate concentrations (using $200 \mathrm{~g} / \mathrm{kg}$ thickening agent, $50 \mathrm{~g} / \mathrm{kg}$ urea and $10 \mathrm{~g} / \mathrm{kg}$ reactive dye)

\begin{tabular}{|c|c|c|c|c|c|c|}
\hline \multirow{2}{*}{$\begin{array}{c}\text { Sodium } \\
\text { bicarbonate conc. } \\
(\mathrm{g} / \mathrm{kg})\end{array}$} & \multirow{2}{*}{$\begin{array}{l}\text { Viscosity } \\
\text { (cP) }\end{array}$} & \multicolumn{3}{|c|}{ Color value } & \multirow{2}{*}{$\begin{array}{l}\text { Color strength } \\
(\mathrm{K} / \mathrm{S})\end{array}$} & \multirow{2}{*}{$\begin{array}{l}\text { Obtained } \\
\text { color }\end{array}$} \\
\hline & & $\mathrm{L}^{*}$ & $a^{*}$ & $b^{*}$ & & \\
\hline 1 & 3,841 & 80.06 & -0.33 & -23.41 & 1.04 & 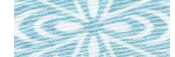 \\
\hline 5 & 3,809 & 68.20 & -4.24 & -15.16 & 1.38 & \\
\hline 10 & 3,792 & 66.31 & -3.55 & -24.95 & 1.43 & $\sqrt{15}$ \\
\hline 15 & 3,788 & 57.17 & -2.86 & -28.33 & 2.57 & STave \\
\hline 20 & 3,782 & 53.88 & -2.56 & -28.96 & 3.25 & 9015 \\
\hline
\end{tabular}




\section{Effect of steaming fixation time}

Steam serves as a convenient source of both water and heat that can be rapidly and uniformly applied to the surface of printed cotton fabrics. Superheated steam is utilized as it heats more quickly, provides shorter dye fixation time, and results in less color spreading. ${ }^{44,47-50}$ Table 6 shows the effect of steaming time, at $110{ }^{\circ} \mathrm{C}$ for 1-30 min, on the reactive dye print depth. It is clearly noted that within the range examined and for the given printing conditions, the $\mathrm{K} / \mathrm{S}$ values of the obtained prints improved by extending the steaming time up to $10 \mathrm{~min}$. Meanwhile, further steaming time, i.e. beyond $20 \mathrm{~min}$, resulted in a negative impact on the K/S values, irrespective of the thickening agent and cotton substrate used (as may be noted in Table 6). This can be explained in terms of: (i) accelerating the tendency towards hydrolysis of the reactive dye used, hence minimising the ability of the dye to form covalent bonds with the hydroxyl group, (ii) adversely affecting the thickener film properties, thus impeding the release of the entrapped reactive dye molecules, (iii) enabling alkaline attack on the dye-fibre bonds, thereby lowering the K/S values of the obtained reactive prints. ${ }^{55}$ Furthermore, prolonged steaming time would also provide sufficient moisture for the moisture absorbing agent (urea) to absorb it. As a result of the combination effect, hydrolysis may occur and reduce color strength.

Table 5

Viscosity, color value, color strength, and obtained color at varying reactive dye concentrations (using $200 \mathrm{~g} / \mathrm{kg}$ thickening agent, $50 \mathrm{~g} / \mathrm{kg}$ urea and $10 \mathrm{~g} / \mathrm{kg}$ sodium bicarbonate)

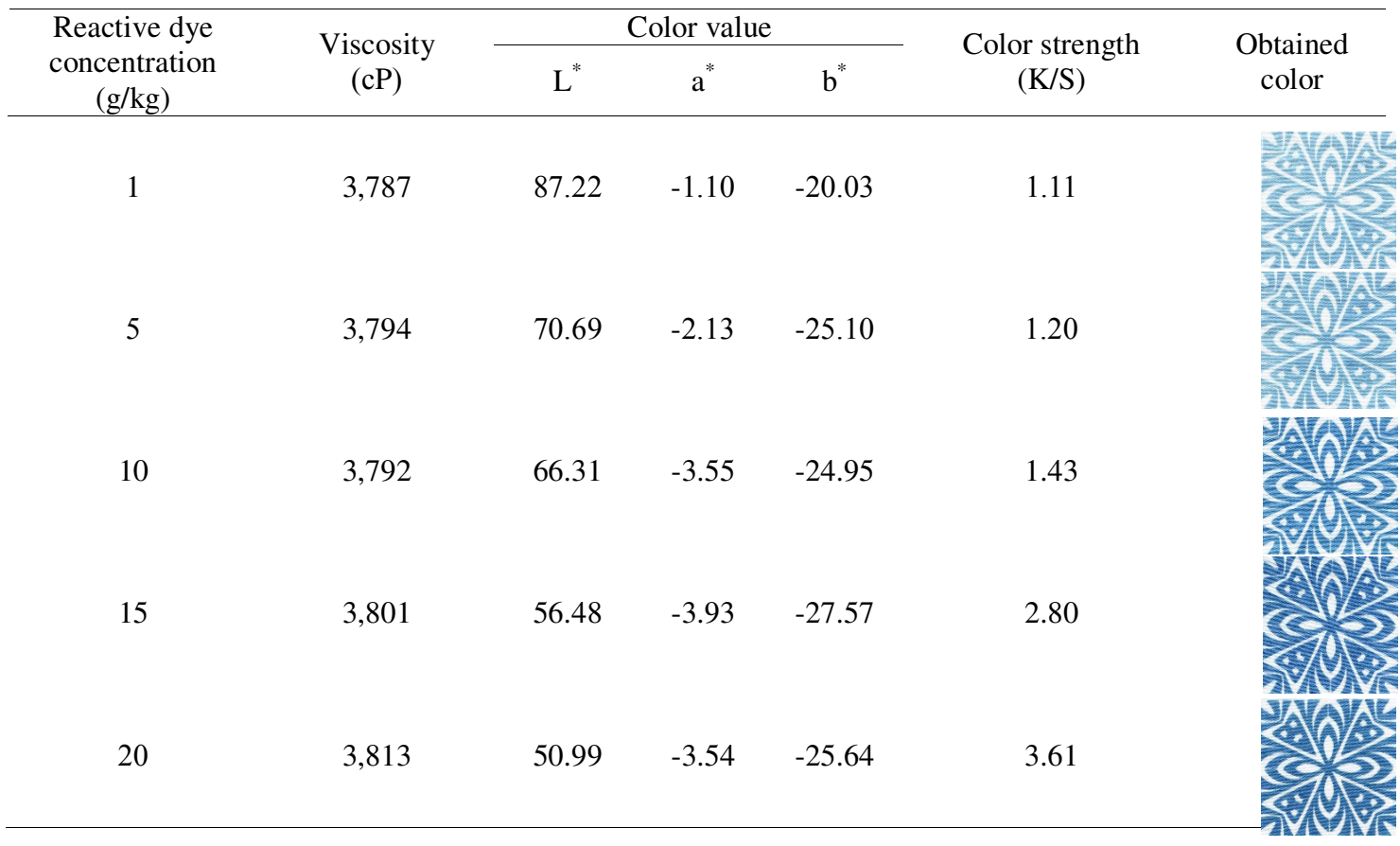

\section{Fastness and physical properties}

Tables 7-9 list the color fastness and physical properties of the cotton fabric printed with 200 $\mathrm{g} / \mathrm{kg}$ paste of thickening agent, $50 \mathrm{~g} / \mathrm{kg}$ paste of urea, $10 \mathrm{~g} / \mathrm{kg}$ paste of sodium carbonate, and 10 $\mathrm{g} / \mathrm{kg}$ paste of reactive dye. The ratings achieved for color fastness to washing, water and perspiration, in terms of degree of color change and color staining, were very good (4-5), as shown in Table 7. The results also showed that the printed cotton fabric sample had good (5) light fastness. As shown in Table 8, the printed cotton fabric had very good (4-5) wet and dry rubbing fastness. This may be due to the alkaline fixed bonds between the fiber and dye particles. As a result, the fabrics printed with reactive dye demonstrated excellent fastness grading due to the 


\section{RATTANAPHOL MONGKHOLRATTANASIT et al.}

strong covalent bond between the reactive dye molecules and the fiber. ${ }^{56}$

The tensile and tearing strengths of unprinted and printed cotton fabrics were assessed in both warp and weft directions and the results are shown in Table 9. It can be seen from the table that the strength of the printed fabric is slightly decreased when compared to the unprinted fabric, along the warp and weft directions. The decrease in the tensile and tearing strength may be attributed to both the degradation of cotton fiber and breaking of internal structural elements. ${ }^{57}$ The stiffness or bending length was increased after printing when compared with the unprinted sample. The bending length of the unprinted cotton fabric was $2.4 \mathrm{~cm}$ in warp direction and 2 $\mathrm{cm}$ in weft direction.

Table 6

Viscosity, color value, color strength, and obtained color at varying fixation time of steaming at $110^{\circ} \mathrm{C}$ (using $200 \mathrm{~g} / \mathrm{kg}$ thickening agent, $50 \mathrm{~g} / \mathrm{kg}$ urea, $10 \mathrm{~g} / \mathrm{kg}$ sodium bicarbonate and $10 \mathrm{~g} / \mathrm{kg}$ reactive dye)

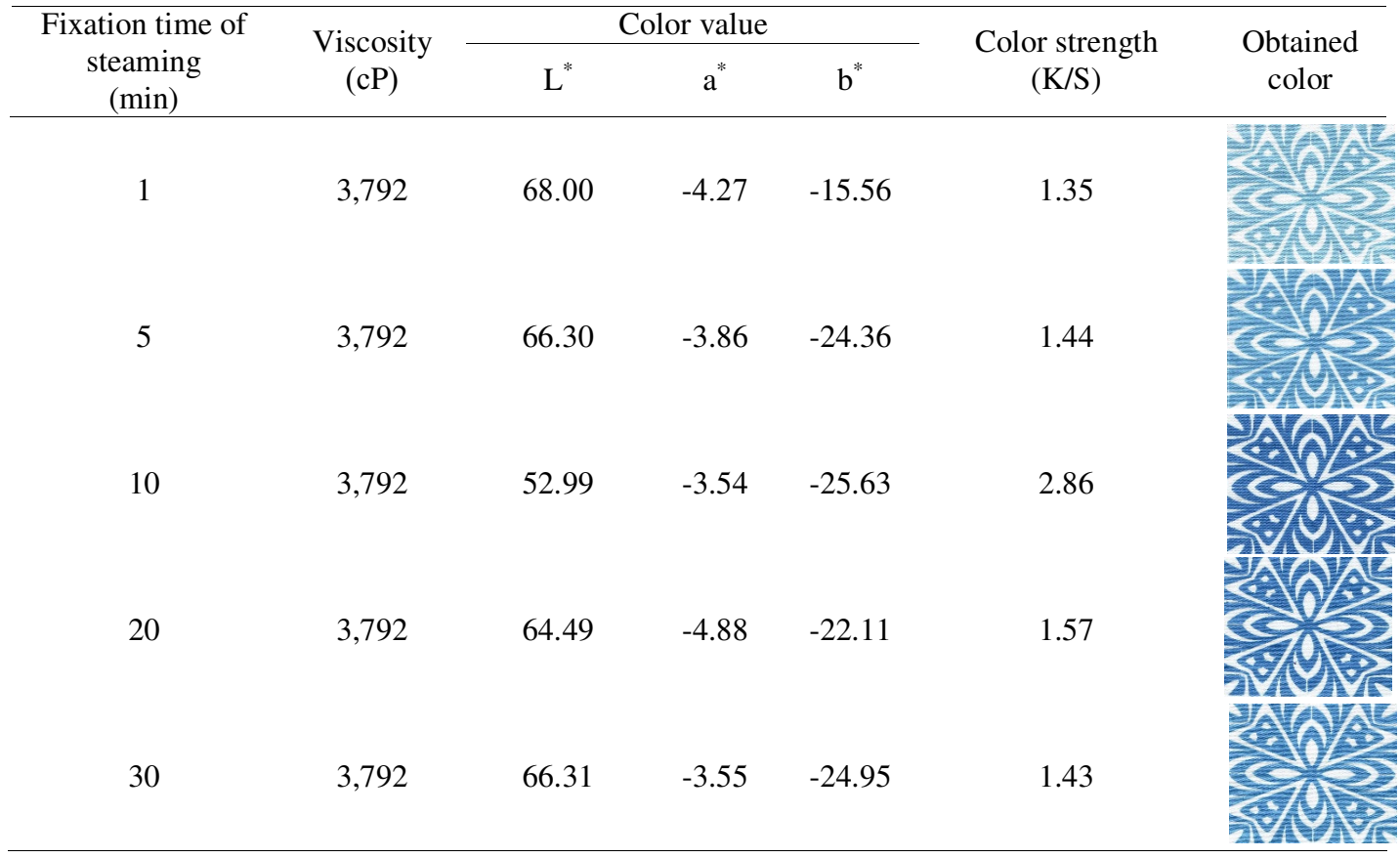

Table 7

Color fastness to washing (ISO 105-C06 A1S: 2010), water (ISO 105-E01: 2013), perspiration

(ISO 105-E04: 2013) and light (ISO 105-B02: 1994)

\begin{tabular}{lccccc}
\hline \multirow{2}{*}{ Fastness } & \multicolumn{5}{c}{ Color fastness to } \\
\cline { 2 - 6 } & \multirow{2}{*}{ Washing } & Water & Light & \multicolumn{2}{c}{ Perspiration } \\
\cline { 5 - 6 } & $4-5$ & $4-5$ & 5 & $4-5$ & $4-5$ \\
Color change & & & & & \\
Color staining & $4-5$ & $4-5$ & - & $4-5$ & $4-5$ \\
-Acetate & $4-5$ & $4-5$ & - & $4-5$ & $4-5$ \\
-Cotton & $4-5$ & $4-5$ & - & $4-5$ & $4-5$ \\
-Nylon & $4-5$ & $4-5$ & - & $4-5$ & $4-5$ \\
-Polyester & $4-5$ & $4-5$ & - & $4-5$ & $4-5$ \\
-Acrylic & $4-5$ & $4-5$ & - & $4-5$ & $4-5$ \\
-Wool & & & & & \\
\hline
\end{tabular}


Table 8

Color fastness to rubbing (ISO 105-X12: 2001)

\begin{tabular}{cccc}
\hline \multicolumn{4}{c}{ Color staining } \\
\hline \multicolumn{3}{c}{ Warp direction } & \multicolumn{2}{c}{ Weft direction } \\
\hline Dry & Wet & Dry & Wet \\
\hline $4-5$ & $4-5$ & $4-5$ & $4-5$
\end{tabular}

Table 9

Tensile strength, tear strength, and stiffness values

\begin{tabular}{lcccc}
\hline \multirow{2}{*}{ Physical properties } & \multicolumn{2}{c}{ Unprinted fabric } & \multicolumn{2}{c}{ Printed fabric } \\
\cline { 2 - 5 } & Warp & Weft & Warp & Weft \\
\hline Tensile strength $(\mathrm{N})$ & 583.00 & 350.80 & 571.40 & 342.60 \\
Tear strength $(\mathrm{N})$ & 7.06 & 9.94 & 6.92 & 9.26 \\
Bending length $(\mathrm{Cm})$ & 2.40 & 2.00 & 2.51 & 2.10 \\
\hline
\end{tabular}

After printing with reactive dye, the bending length increased to $2.51 \mathrm{~cm}$ warp way and $2.1 \mathrm{~cm}$ weft way (Table 9). The increase in bending length may be due to the use of the thickening agent for the preparation of the printing paste ${ }^{32}$ and the remaining trace of printing paste after the washing-off step. ${ }^{58}$

\section{CONCLUSION}

In this work, we applied modified starch of wild taro corms as a new thickening agent for screen-printing of cotton fabrics using reactive dye. Various concentrations of thickening agent, urea, sodium bicarbonate, reactive dye, and steaming fixation time were investigated. The results revealed that increasing the thickening agent concentration up to $200 \mathrm{~g} / \mathrm{kg}$ paste, the urea concentration up to $100 \mathrm{~g} / \mathrm{kg}$ paste, the sodium bicarbonate concentration up to $20 \mathrm{~g} / \mathrm{kg}$ paste, and the reactive dye concentration up to $20 \mathrm{~g} / \mathrm{kg}$ paste resulted in enhancing the depth of the prints obtained. Optimal steaming fixation was established to be achieved at $110{ }^{\circ} \mathrm{C}$ for $10 \mathrm{~min}$. The color fastness rating to washing, perspiration, and rubbing of the printed samples was good. The color fastness to light was also good. The tensile and tearing strength values of the printed cotton fabrics were lower than those of the unprinted fabric. The printed cotton fabric also showed increased stiffness. This study has demonstrated that the modified thickening agent obtained from wild taro corms would have extensive application in reactive dye printing on cotton fabric. Therefore, it could provide a viable option for cottage industries for developing value-added products and diversifying their production.
ACKNOWLEDGEMENT: The authors gratefully acknowledge the financial support of the Thailand Toray Science Foundation (TTSF): Science \& Technology Research Grant. Authors are thankful to Rajamangala University of Technology Phra Nakhon (RMUTP), Thailand, for supporting this research.

\section{REFERENCES}

1 S. Pradhan, N. Fatima and E. Sharma, Int. J. Appl. Res., $\quad 1, \quad 1027 \quad$ (2015), https://www.allresearchjournal.com/archives/?year=20 $15 \&$ vol $=1 \&$ issue $=9 \&$ part $=$ P\&ArticleId $=709$

2 S. Arora, Int. J. Home Sci., 2, 20 (2016), https://www.homesciencejournal.com/archives/?year= $2016 \&$ vol $=2 \&$ issue $=3 \&$ part $=$ A\&Article $I d=158$

3 C. M. Obele, M. E. Ibenta, J. L. Chukwuneke and S. C. Nwanonenyi, Cellulose, 28, 2615 (2021), https://doi.org/10.1007/s10570-021-03694-0

4 J. Huang, L. Wang, T. Li and J. Shao, Text. Res. J., 88, 614

(2018),

https://doi.org/10.1177/0040517516685275

5 C. R. Madhu and M. C. Patel, Int. Res. J. Eng. $\begin{array}{llll}\text { Tech., } & \text { 3, } & 1418\end{array}$ https://www.irjet.net/archives/V3/i3/IRJETV3I3297.pdf

6 A. Borisova, IOP Conf. Ser. Mater. Sci. Eng., 500, 1 (2019), https://doi.org/10.1088/1757$899 X / 500 / 1 / 012028$

7 B. Zhang, H. Gong, S. Lü, B. Ni, M. Liu et al., Int. J. Biol. Macromol., 51, $668 \quad$ (2012), https://doi.org/10.1016/j.ijbiomac.2012.07.003

8 M. S. Rahman, M. S. Hasan, A. S. Nitai, S. Nam, A. K. Karmakar et al., Polymers, 13, 1 (2021), https://doi.org/10.3390/polym13081345

9 S. Islam, M. Shahid and F. Mohammad, J. Clean. Prod., $\quad 57, \quad 2013$, https://doi.org/10.1016/j.jclepro.2013.06.004

10 A. Kukrety, R. K. Singh, P. Singh and S. S. Ray, Waste Biomass Valoriz., 9, 1587 (2018), https://doi.org/10.1007/s12649-017-9903-3 
11 A. Abdulhameed, IOSR J. Appl. Chem., 12, 33 (2020), https://doi.org/10.9790/5736-1212013342

12 M. Kanik and P. J. Hauser, Color. Technol., 118, $300 \quad$ (2002), https://doi.org/10.1111/j.14784408.2002.tb00114.x

13 L. Wang, X. Wang and Y. Shen, Cellulose, 24, 1077 (2017), https://doi.org/10.1007/s10570-0161124-6

14 L. Wang, X. Wang, Y. Shen, J. Shao and F. Pei, Text. Res. J., 88, $1766 \quad$ (2018), https://doi.org/10.1177/0040517517708541

15 A. Yavas, A. T. Ozguney, O. O. Avinc and E. Kalayci, in Procs. $8^{\text {th }}$ International ScientificProfessional Conference on Textile Science and Economy VIII, Zrenjanin, May 16-19, 2016, pp. 213220,

http://www.tfzr.uns.ac.rs/tnp/files/Zbornik\%202016.pd $\mathrm{f}$

16 A. Ivancic and V. Lebot, Pac. Sci., 53, 273 (1999), https://core.ac.uk/download/pdf/5094512.pdf

17 L. S. Nelson and K. D. Getsinger, J. Aquat. Plant Manag., $\quad 38, \quad 70 \quad$ (2000), http://www.apms.org/japm/vol38p70.pdf

18 K. C. M. Thampatti, V. I. Beena, A. V. Meera and A. S. Ajayan, in "Phytoremediation", edited by B. R. Shmaefsky, 2020, Springer Nature Switzerland AG, pp. 153-204, https://doi.org/10.1007/978-3-030-000998

9 R. Kumar, J. Pharmacogn. Phytochem., 8, 1210 (2019),

https://www.phytojournal.com/archives/2019/vol8issu e3/PartV/8-2-605-958.pdf

20 K. Cha-um, S. Sangjun, K. Prawetchayodom, C. Theerawitaya, R. Tisarum et al., J. Hortic., 88, 499 (2019), https://doi.org/10.2503/hortj.UTD-021

21 L. A. Cozad, N. Harms, A. D. Russell, M. D. Souza and R. Diaz, J. Aquat. Plant Manag., 56, 1 (2018), https://aquadocs.org/handle/1834/19681

22 O. S. Lawal, M. D. Lechner and W. M. Kulicke, Polym. Degrad. Stabil., 93, 1520 (2008), https://doi.org/10.1016/j.polymdegradstab.2008.05.010 23 L. F. Wang, S. Y. Pan, H. Hu, W. H. Miao and X. Y. Xu, Carbohyd. Polym., 80, 174 (2010), https://doi.org/10.1016/j.carbpol.2009.11.008

${ }^{24}$ L. Kan, Q. Zhao, J. Hu, Y. Wu and J. Ouyang, J. Food Process. Preserv., 41, 1 (2017), https://doi.org/10.1111/jfpp.13229

${ }^{25}$ Z. Xiaodong, L. Xin and L. Wenying, J. Appl. Polym. Sci., 89, $3016 \quad$ (2003), https://doi.org/10.1002/app.12438

26 H. Qiu and L. He, Polym. Adv. Technol., 10, 468 (1999), https://doi.org/10.1002/(SICI)10991581(199907)10:7<468::AID-PAT898>3.0.CO;2-W

27 V. V. Shinde, Indian J. Nat. Prod. Resour., 4, 466 (2005),

http://nopr.niscair.res.in/bitstream/123456789/8142/1/ NPR\%204(6)\%20466-470.pdf
28 C Seidel, W. M. Kulicke, C. Heß, B. Hartmann, M. D. Lechner et al., ., Starch-Stärke, 56, 157 (2004), https://doi.org/10.1002/star.200200165

29 S. Abd-Aziz, J. Biosci. Bioeng., 94, 526 (2002), https://doi.org/10.1016/S1389-1723(02)80190-6

30 P. Goyal, V. Kumar and P. Sharma, Carbohyd. Polym., $\quad$ 69, $251 \quad$ (2007), https://doi.org/10.1016/j.carbpol.2006.10.001

31 R. Mongkholrattanasit, C. Klaichoi, N. Sasithorn, W. Changmuang, K. Manarungwit et al., Vlak. Textil., 25, 51 (2018), http://vat.ft.tul.cz/2018/3/VaT_2018_3_8.pdf

${ }^{32}$ R. Mongkholrattanasit, C. Klaichoi, N. Rungruangkitkrai, N. Vuthiganond and M. Nakpathom, J. Nat. Fibers, (2021), https://doi.org/10.1080/15440478.2021.1875381

33 V. Pushpamalar, S. J. Langford, M. Ahmad and Y. Y. Lim, Carbohyd. Polym., 64, 312 (2006), https://doi.org/10.1016/j.carbpol.2005.12.003

34 N. Punrattanasin, M. Nakpathom, B. Somboon, N. Narumol, N. Rungruangkitkrai et al., Ind. Crop. Prod., 49, $122 \quad$ (2013), https://doi.org/10.1016/j.indcrop.2013.04.041

35 I. Abd El-Thalouth, M. Rekaby, A. H. AbdelRahman and S. A. El-Khabery, Res. J. Text. Appar., 16, 68 (2012), https://doi.org/10.1108/RJTA-16-012012-B007

36 E. M. R. El-Zairy, Autex Res. J., 11, 66 (2011), https://www.autexrj.com/cms/zalaczone_pliki/7_011_1 1.pdf

37 R. Mongkholrattanasit, C. Saiwan, N. Rungruangkitkrai, N. Punrattanasin, K. Sriharuksa et al., J. Text. Inst., 106, 1106 (2015), https://doi.org/10.1080/00405000.2014.976957

38 R. Mongkholrattanasit, C. Saiwan, N. Rungruangkitkrai, N. Punrattanasin, K. Sriharuksa et al., J. Nat. Fibers, 13, 65 (2016), https://doi.org/10.1080/15440478.2014.984056

39 N. A. Ibrahim, M. H. Abo-Shosha, E. A. Allam and E. M. El-Zairy, Polym. Plast. Technol. Eng., 47, 389 (2008), https://doi.org/10.1080/0360255080189766

40 D. G. Duff and R. S. Sinclair, "Giles's Laboratory Course in Dyeing", Society of Dyers and Colourists, West Yorkshire, 1989

41 C. H. Giles, "A Laboratory Course in Dyeing", Society of Dyers and Colourists, West Yorkshire, 1974

${ }^{42}$ R. Mongkholrattanasit, J. Kryštůfek, J. Wiener and J. Studničková, in "Natural Dyes", edited by A. K. Emriye, Intech Publisher, 2011, pp. 57-78, https://www.intechopen.com/chapters/23052

43 A. K. Sarkar and C. M. Seal, Cloth. Text. Res. J., 21, $162 \quad$ (2003), https://doi.org/10.1177/0887302X0402100402

44 C. W. M. Yuen, S. K. A. Ku, P. S. Choi and C. W. Kan, Res. J. Text. Apparel, 7, 43 (2003), http://dx.doi.org/10.1108/RJTA-07-02-2003-B006

45 S. H. A. S. Hassan, G. M. E. Gamal and G. H. E. Nady, Architecture, Arts Humanistic Sci. Mag., 29, 1 (2018), https://platform.almanhal.com/Files/2/115878 
46 M. Glogar, J. Tancik, I. Brlek, A. Sutlovic and M. Tkalec, Color. Technol., 136, 188 (2020), https://doi.org/10.1111/cote.12462

47 C. W. M. Yuen, S. K. A. Ku, P. S. Choi and C. W. Kan, Fibers Polym., 5, 117 (2004), https://doi.org/10.1007/BF02902924

48 P. S. R. Choi, C. W. M. Yuen, S. K. A. Ku and C. W. Kan, Fibers Polym., 6, 229 (2005), https://doi.org/10.1007/BF02875647

49 C. W. M. Yuen, S. K. A. Ku and C. W. Kan, J. Appl. Polym. Sci., 107, 1057 (2008), https://doi.org/10.1002/app.26968

50 H. Zhang, J. Wang, K. Xie, L. Pei and A. Hou, Dyes Pigm., 174, 1 (2020), https://doi.org/10.1016/j.dyepig.2019.108079

51 M. Li, A. Gao, L. Wu, D. Fu and K. Xie, Text. Res. J., 87, $2127 \quad$ (2017), https://doi.org/10.1177/0040517516665256

52 M. D. Teli, S. P. Valia and C. Pradhan, J. Text. Assoc., 75, http://a.xueshu.baidu.com/usercenter/paper/show?pape rid $=$ aa5c798531da4735c3abc555e34bafe7

53 M. Rekaby, A. A. Salem and S. H. Nassar, J. Text. Inst., 100 , 486 (2009), https://doi.org/10.1080/00405000801962177

54 F. A. Ben, W. Miled, W. Haddar and N. Meksi, Chem. Ind. Chem. Eng. Q., 27, 1 (2021), https://doi.org/10.2298/CICEQ191004019B

55 N. A. Ibrahim, M. H. Abo-Shosha, E. A. M. R. El-Zairy and E. M. El-Zairy, J. Appl. Polym. Sci., 101, 4430 (2006), https://doi.org/10.1002/app.23689

56 D. Paul, S. C. Das, T. Islam, M. A. B. Siddiquee and M. A. A. Mamum, J. Chem. Chem. Eng., 11, 162 (2017), https://doi.org/10.17265/19347375/2017.04.004

57 S. C. O. Ugbolue and S. M. Aula, J. Appl. Polym. Sci., 25, 1071 (1980), https://doi.org/10.1002/ app. 1980.070250609

${ }_{58}$ V. Kokol, S. Š. Turk and R. Schneider, Text. Res. J., 72, 211 (2002), https://doi.org/ 10.1177/ 004051750207200305 